\title{
Weak acid preservatives block the heat shock response and heat-shock-element-directed lacz expression of low pH Saccharomyces cerevisiae cultures, an inhibitory action partially relieved by respiratory deficiency
}

\author{
Lili Cheng and Peter W. Piper
}

Author for correspondence: Peter W. Piper. Tel: +44 713877050 ext. 2212. Fax: +44 713807193.

Department of Biochemistry and Molecular Biology, University College London, London WC1E 6BT, UK
Inhibition of microbial growth by weak acid preservatives increases with medium acidification, since these agents enter cells in the undissociated state. Many of the effects of these acids are due to the cytoplasmic acidification they cause as they dissociate in the higher pH environment of the cytosol. Sorbic and benzoic acids, two widely used preservatives, were found to exert pronounced effects on the heat shock response and thermotolerance of Saccharomyces cerevisiae. These effects were strongly influenced by the pH of the culture medium. In low pH cultures sorbate inhibited the induction of thermotolerance by sublethal heat shock, causing strong induction of respiratory-deficient petites among the survivors of heat treatment. However, when the culture pH was above 5.5 sorbate acted as a powerful chemical inducer of thermotolerance in the absence of any sublethal heat treatment. Sorbate and benzoate also inhibited heat induction of the major heat shock proteins in low pH yeast cultures. This appears to result from lack of induction of the heat shock element (HSE) promoter sequence since sorbate prevented heat induction of a HSE-lacZ fusion at low pH. The uncoupler carbonyl cyanide $m$-chlorophenylhydrazone (CCCP) and the plasma-membrane-ATPase inhibitor diethylstilboestrol were identified as additional inhibitors of heat induction of heat shock proteins. Numerous chemicals induce the heat shock response in the absence of heat stress, but sorbate, benzoate, CCCP and diethylstilboestrol are the first compounds shown to act as selective inhibitors of heat-induced protein expression in yeast. In the presence of sorbate concentrations which, at low pH, totally inhibit both the heat shock response and growth of cells competent in respiration, respiratory-deficient petites still retain a limited capacity for growth and for heat induction of heat shock proteins. This restoration of a response to heat shock in acidified sorbate-treated cultures of petites might contribute to their higher capacity for growth in the presence of sorbate.

Keywords: Saccharomyces cerevisiae, weak acid preservatives, heat shock element, thermotolerance, intracellular $\mathrm{pH}$

\section{INTRODUCTION}

Sorbic and benzoic acids are in extensive use as food preservatives since they inhibit the growth of fungi and

Abbreviations: PFK1, 6-phosphofructo-1-kinase; $\mathrm{pH}_{\mathrm{i}}$ intracellular $\mathrm{pH}$; CCCP, carbonyl cyanide $\bar{m}$-chlorophenylhydrazone; HSE, heat shock element. bacteria. It has been clearly established that the penetration of these acids into cells and growth inhibition both increase with medium acidification, being essentially proportional to the concentration of undissociated acid (for literature see Russell, 1991). Following entry to the cells of low $\mathrm{pH}$ cultures as undissociated forms, sorbic and benzoic acids dissociate in the higher $\mathrm{pH}$ of the cytosol to cause intracellular acidification. In Saccharomyces 


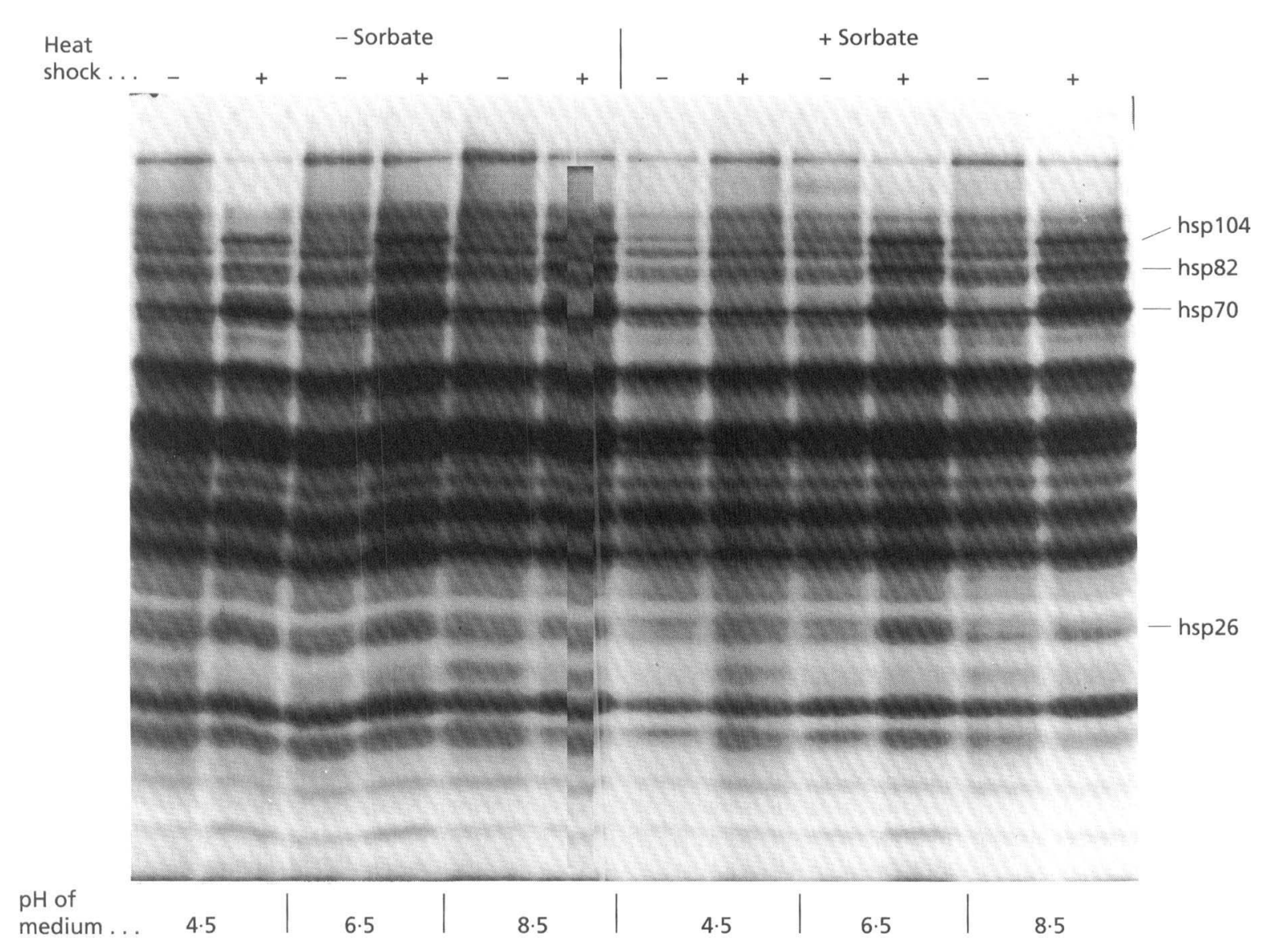

Fig. 1. Proteins labelled in S. cerevisiae incubated with $\left[{ }^{3} \mathrm{H}\right]$ leucine for $40 \mathrm{~min}$, either at $25^{\circ} \mathrm{C}(-)$ or immediately after heat shock to $39^{\circ} \mathrm{C}(+)$ in the presence and absence of $9 \mathrm{mM}$ potassium sorbate. Prior to labelling the cells were resuspended in medium buffered at pH 4.5, 6.5 or 8.5 (see Methods). The heat shock proteins induced most strongly by heat shock (Mager \& Moradas-Ferreira, 1993) are indicated to the right of the figure.

cerevisiae intracellular $\mathrm{pH}\left(\mathrm{pH}_{\mathrm{i}}\right)$ declines more than 1 unit with 2-10 $\mathrm{mM}$ benzoate, this $\mathrm{pH}_{\mathrm{i}}$ depression causing an inhibition of 6-phospho-1-fructokinase (PFK1) that reduces glycolytic flux (Krebs et al., 1983; Francois $e t$ al., 1986, 1988a, b). More osmotolerant yeasts, notably Zygosaccharomyces bailii, are important causative agents of the spoilage of low $\mathrm{pH}$ foods and beverages of high sugar content (Thomas \& Davenport, 1985). They are able to undergo an adaption that allows growth in the presence of preservative concentrations in excess of those permitted legally in foodstuffs (Warth, 1978, 1988; Cole \& Keenan, 1986, 1987). In $S$. cerevisiae both respiration and fermentation are inhibited by weak acids (Krebs et al., 1983; Francois et al., 1986, 1988a, b), whereas in Z. bailii respiration is totally inhibited by weak acid concentrations that have little effect on fermentation (Cole, 1987).

A mild, sublethal heat stress increases the capacity of microbial cells to survive during a subsequent exposure to higher, potentially lethal temperatures. This development of the state of induced or 'acquired' thermotolerance is widespread amongst food-contaminating and pathogenic organisms and therefore a phenomenon having major implications for microbiological safety (Piper, 1993). A mild heat stress also induces the highly conserved heat shock proteins in all cells (Lindquist \& Craig, 1988; Watson, 1990; Mager \& Moradas-Ferreira, 1993). The literature regarding the effects of weak acid preservatives on the heat tolerance of yeast is confusing, sorbate having been variously reported as either not affecting (Van Uden, 1984) or increasing (Coote et al., 1991) S. cerevisiae thermotolerance. We report here that the effects of sorbate on yeast thermotolerance are strongly dependent on extracellular $\mathrm{pH}$, and also that heating low $\mathrm{pH}$ cultures with sorbate causes strong induction of respiratorydeficient petites. This indicates that heat potentiates the sorbate-induced ultrastructural damage to yeast mitochondria seen in electron micrographs (Cole, 1987).

This study also revealed sorbate and benzoate acting as selective inhibitors of the heat induction of heat shock genes in yeast cultures of low $\mathrm{pH}$. Numerous chemicals induce the synthesis of heat shock proteins in the absence of heat stress (Anathan et al., 1985; Lindquist \& Craig, 1988; Watson, 1990), but very few agents are known to selectively inhibit heat induction of these same proteins. 


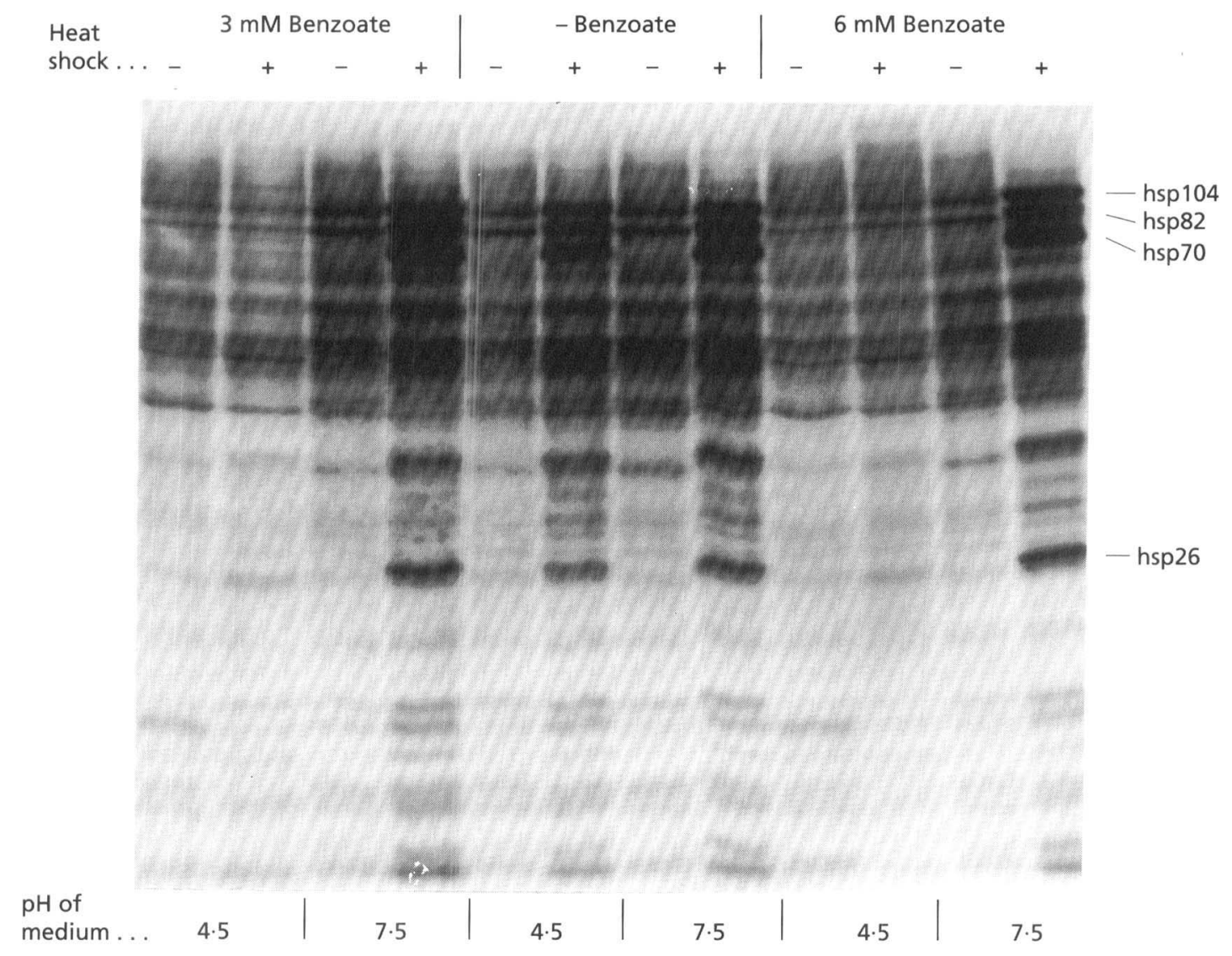

Fig. 2. Proteins labelled in S. cerevisiae incubated with $\left[{ }^{3} \mathrm{H}\right]$ leucine for $40 \mathrm{~min}$, either at $25^{\circ} \mathrm{C}(-)$ or immediately after heat shock to $39^{\circ} \mathrm{C}(+)$ in the absence and presence of benzoate. Cells had previously been resuspended in medium buffered at $\mathrm{pH} 4.5$ or 7.5 .

The only other selective inhibitors reported are flavonoids, which cause hypersensitization to heat and a block to the expression of heat shock proteins in mammalian cells (Hosokawa et al., 1990). Other agents, including a flavonoid, were therefore tested for their ability to block heat shock protein induction in yeast.

Incubation of low $\mathrm{pH}$ S. cerevisiae cultures in the presence of sorbate can provide a strong selection for respiratorydeficient petites. This is because the petite mutation confers the capacity for slow growth at sorbate levels that cause a total inhibition of the growth of cells competent for respiration. This mutation also partially restores the capacity for a heat shock response at low $\mathrm{pH}$ in the presence of sorbate.

\section{METHODS}

Strains and materials. All experiments were conducted using $S$. cerevisiae strain SUB62 (a leu2, trp1, ura3, bis3, lys2; gift of D. Finley) or the SUB62-derived transformant SUB62-pHSE2 [SUB62 transformed with pHSE2, a $U R A 3$-bearing plasmid that carries a heat-shock-inducible lac $Z$ gene (Kirk \& Piper, 1991)]. pHSE2 possesses a tandem copy of the heat shock element (HSE) sequence that directs heat shock induction of many yeast genes, inserted within a CYC1 promoter-lacZ gene fusion (HSE-lacZ) in place of the normal CYC1 upstream activating sequences (Sorger \& Pelham, 1987). Spontaneous petites derived from SUB62 and SUB62-pHSE2 were isolated as small colonies on YPD medium [2\% Bactopeptone, $1 \%$ yeast extract, $2 \%$ glucose (all \%, w/v)] plates containing $1.5 \%$ agar, cells being plated after high temperature $\left(38^{\circ} \mathrm{C}\right)$ growth for five generations, a condition which enriches for petites (Van Uden, 1984). Sorbate-induced petites were survivors from the $\mathrm{pH} 4.5$ sorbate-treated cells of the experiment in Fig. 4(b). Petites were scored as colonies capable of fermentative growth on YPD but not respiratory growth on YPG (2\% Bactopeptone, $1 \%$ yeast extract, $2 \%$ glycerol, $1.5 \%$ agar) plates.

Yeast culture. Cultures of SUB62 were grown either on liquid YPD medium or, for protein labelling, on SD minimal dextrose medium $[0.67 \%, \mathrm{w} / \mathrm{v}$, yeast nitrogen base (Difco), $2 \%, \mathrm{w} / \mathrm{v}$, glucose plus uracil, leucine, histidine, tryptophan and lysine supplements (Sherman et al., 1983)]. SUB62-pHSE2 was grown on the same medium minus uracil to ensure maintenance of the pHSE2 plasmid. Flask cultures were shaken at $25^{\circ} \mathrm{C}$ to ensure aeration and used for experiments when in early exponential phase at $5 \times 10^{6}-1 \times 10^{7}$ cells $\mathrm{ml}^{-1}$. CCCP, potassium benzoate and potassium sorbate (all from Sigma) were added from $\mathrm{pH} 70.1 \mathrm{M}, 0.6 \mathrm{M}$ and $0.9 \mathrm{M}$ stock solutions respectively; and diethylstilboestrol (Sigma) from a $2.7 \mathrm{mg} \mathrm{m}^{-1}$ solution in methanol.

Protein labelling at different pH values. For protein labelling, SD medium SUB62 cultures were centrifuged ( $5 \mathrm{~min}, 2500 \mathrm{~g}$ ) 

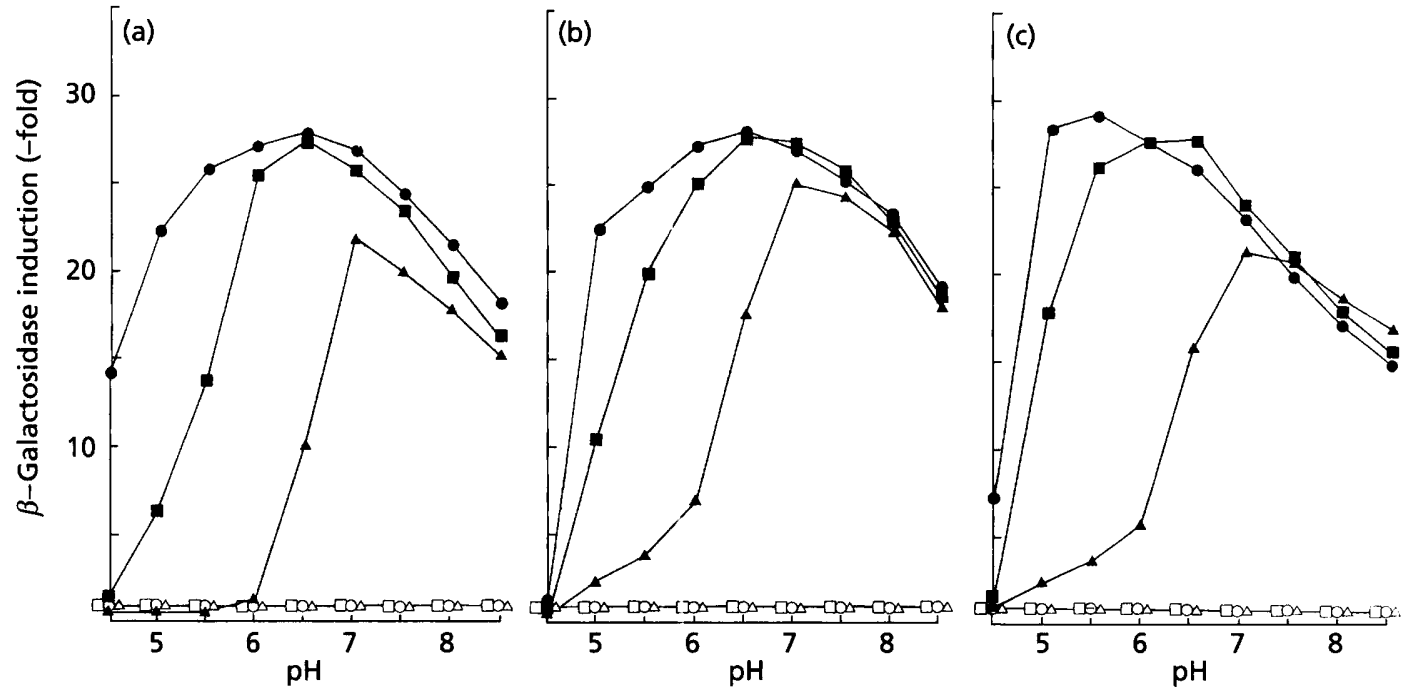

\begin{abstract}
Fig. 3. Influences of medium $\mathrm{pH}$ and sorbate on the expression of a HSE-lacZ fusion in SUB62-pHSE2 (a); in a spontaneous petite derived from SUB62-pHSE2 (b); and in the same petite grown for several generations in the presence of $1 \mathrm{mM}$ sorbate (c). Cells were resuspended in media buffered at different pH values from 4.5 to 8.5 , with or without sorbate. After these cultures had been maintained at $25^{\circ} \mathrm{C}$ or heat shocked to $39{ }^{\circ} \mathrm{C} \beta$-galactosidase levels were determined (see Methods). $\beta$-Galactosidase is given as fold-induction relative to the constant $\beta$-galactosidase level of $2 \cdot 3$ Miller units (Miller, 1972) in uninduced $25^{\circ} \mathrm{C}$ SD medium SUB62-pHSE2 cultures. Basal HSE-lacZ expression in the absence of heat shock was unaffected by either medium pH or sorbic acid, as shown by the low constant $\beta$-galactosidase level at $25^{\circ} \mathrm{C}$ in the absence $(O)$ or the presence of sorbate $(\square, 1 \mathrm{mM} ; \triangle, 9 \mathrm{mM})$. lacZ expression after heat induction of HSE activity showed an appreciable dependence on culture $\mathrm{pH}$ even in the absence of sorbic acid (O). The influences of $1 \mathrm{mM}$ $(\boldsymbol{D})$ or $9 \mathrm{mM}(\boldsymbol{\Delta})$ sorbate on this heat-induced expression are much more pronounced at lower pH values. Also while $9 \mathrm{mM}$ sorbate totally inhibited heat induction of HSE-lacZ expression in SUB62-pHSE2 below pH 6.0 (a), this inhibition was only partial in the petite $(b, c)$.
\end{abstract}

and resuspended at $5 \times 10^{7}-1 \times 10^{8}$ cells $\mathrm{ml}^{-1}$ in $0.5 \times \mathrm{SD}$ medium containing $50 \mathrm{mM}$ of the appropriate buffer (sodium acetate $\mathrm{pH} 4.5 ; \mathrm{MES} / \mathrm{KOH} \mathrm{pH} 6.5 ; \mathrm{TES} / \mathrm{KOH} \mathrm{pH} 7.5$ or TES/KOH $\mathrm{pH} \mathrm{8.5).} \mathrm{Cells} \mathrm{were} \mathrm{incubated} \mathrm{for} 20 \mathrm{~min}$ at $25^{\circ} \mathrm{C}$ in this buffered medium prior to the addition of $0.05 \mathrm{mCi} \mathrm{ml}^{-1}\left(1.85 \mathrm{MBq} \mathrm{ml}^{-1}\right)\left[4,5-{ }^{3} \mathrm{H}\right]$ leucine $\left[53 \mathrm{Ci} \mathrm{mmol}^{-1}\right.$ $\left(1.96 \mathrm{GBq} \mathrm{mmol}^{-1}\right)$ New England Nuclear] and, where indicated, sorbate, benzoate, CCCP or diethylstilboestrol. Labelling was by further incubation for $40 \mathrm{~min}$ at either $25^{\circ} \mathrm{C}$ or, for the heat shocked samples, at $39^{\circ} \mathrm{C}$. Preparation of samples of total in vivo pulse-labelled protein, analysis of these samples on onedimensional $12.5 \%$ SDS-polyacrylamide gels and detection of labelled proteins by fluorography was as in Panaretou \& Piper $(1990,1992)$. Protein determinations were performed using the Bio-Rad protein assay kit and bovine serum albumin as standard.

Effects of extracellular $\mathbf{p H}$ and of sorbic acid on $\beta$-galactosidase expression. SD medium cultures of SUB62-pHSE2 were centrifuged and resuspended at $5 \times 10^{6}-1 \times 10^{7}$ cells $\mathrm{ml}^{-1}$ in $0.5 \times \mathrm{SD}$ medium containing $50 \mathrm{mM}$ of the appropriate buffer (sodium acetate $\mathrm{pH} 4.5$ or 5.0 ; MES/KOH pH $5.5,6.0$ or 6.5 ; TES/KOH pH $7 \cdot 0,7 \cdot 5$ or $8 \cdot 5)$. These buffered SUB62-pHSE2 cultures were incubated for $20 \mathrm{~min}$ at $25^{\circ} \mathrm{C}$, before being divided into four aliquots which were subjected to alternative treatments prior to measurement of $\beta$-galactosidase activity: (i) $60 \mathrm{~min}$ further incubation at $25^{\circ} \mathrm{C}$; (ii) 60 min heat shock at $39^{\circ} \mathrm{C}$; (iii) addition of $1 \mathrm{mM}$ or $9 \mathrm{mM}$ potassium sorbate, followed by $60 \mathrm{~min}$ further incubation at $25^{\circ} \mathrm{C}$; and (iv) addition of $1 \mathrm{mM}$ or $9 \mathrm{mM}$ potassium sorbate, followed by $60 \mathrm{~min}$ heat shock at $39^{\circ} \mathrm{C}$. $\beta$-Galactosidase levels were measured as in Miller (1972).

Effects of extracellular pH and of sorbic acid on thermo- tolerance. SD and YPD medium SUB62 cultures in early exponential phase at $5 \times 10^{6}-1 \times 10^{7}$ cells $\mathrm{ml}^{-1}$ were used for these studies. SD cultures were diluted with an equal volume of a $100 \mathrm{mM}$ solution of the appropriate buffer (sodium acetate $\mathrm{pH} 3.5$ or $4.5 ; \mathrm{MES} / \mathrm{KOH} \mathrm{pH} 5.5$ or $6.5 ; \mathrm{TES} / \mathrm{KOH} \mathrm{pH} 7.5$ or $8 \cdot 5)$. YPD cultures were centrifuged and resuspended at $5 \times 10^{6}-1 \times 10^{7}$ cells $\mathrm{ml}^{-1}$ in YPD previously adjusted to $\mathrm{pH} 3 \cdot 5$, $4 \cdot 5,5 \cdot 5,6 \cdot 5,7 \cdot 5$ or $8 \cdot 5$ with $\mathrm{HCl}$ or $\mathrm{NaOH}$. After either 5 min or $60 \mathrm{~min}$ incubation at $25^{\circ} \mathrm{C}$ or $38^{\circ} \mathrm{C}$ in these buffered media, cultures were immediately heated $5 \mathrm{~min}$ at $50{ }^{\circ} \mathrm{C}$ (for data in Figs 4 and 5), or recentrifuged and resuspended in $\mathrm{pH} 6.0$ sorbate-free YPD prior to $5 \mathrm{~min} 50^{\circ} \mathrm{C}$ heat treatment (for data in Fig. 6). Cell survival, measured as the ability to form colonies on YPD plates at $28^{\circ} \mathrm{C}$, is expressed in Figs 4-6 relative to the survival of the starter SD or YPD cultures subjected to an identical $50^{\circ} \mathrm{C} 5 \mathrm{~min}$ stress. For each time point $>50$ colonies were counted, the data shown being the combined results of two separate experiments.

\section{RESULTS}

\section{Sorbate and benzoate inhibit heat induction of major heat shock proteins in $S$. cerevisiae cultures of low pH}

$S$. cerevisiae cells were resuspended in buffered $0.5 \times \mathrm{SD}$ media of $\mathrm{pH} 4.5,6.5$ or 8.5 . Shortly afterwards they were pulse-labelled with $\left[{ }^{3} \mathrm{H}\right]$ leucine, either at $25{ }^{\circ} \mathrm{C}$ or after a heat shock to $39^{\circ} \mathrm{C}$, and in the absence or presence of $9 \mathrm{mM}$ potassium sorbate (see Methods). One-dimensional gel electrophoresis of proteins labelled under these 

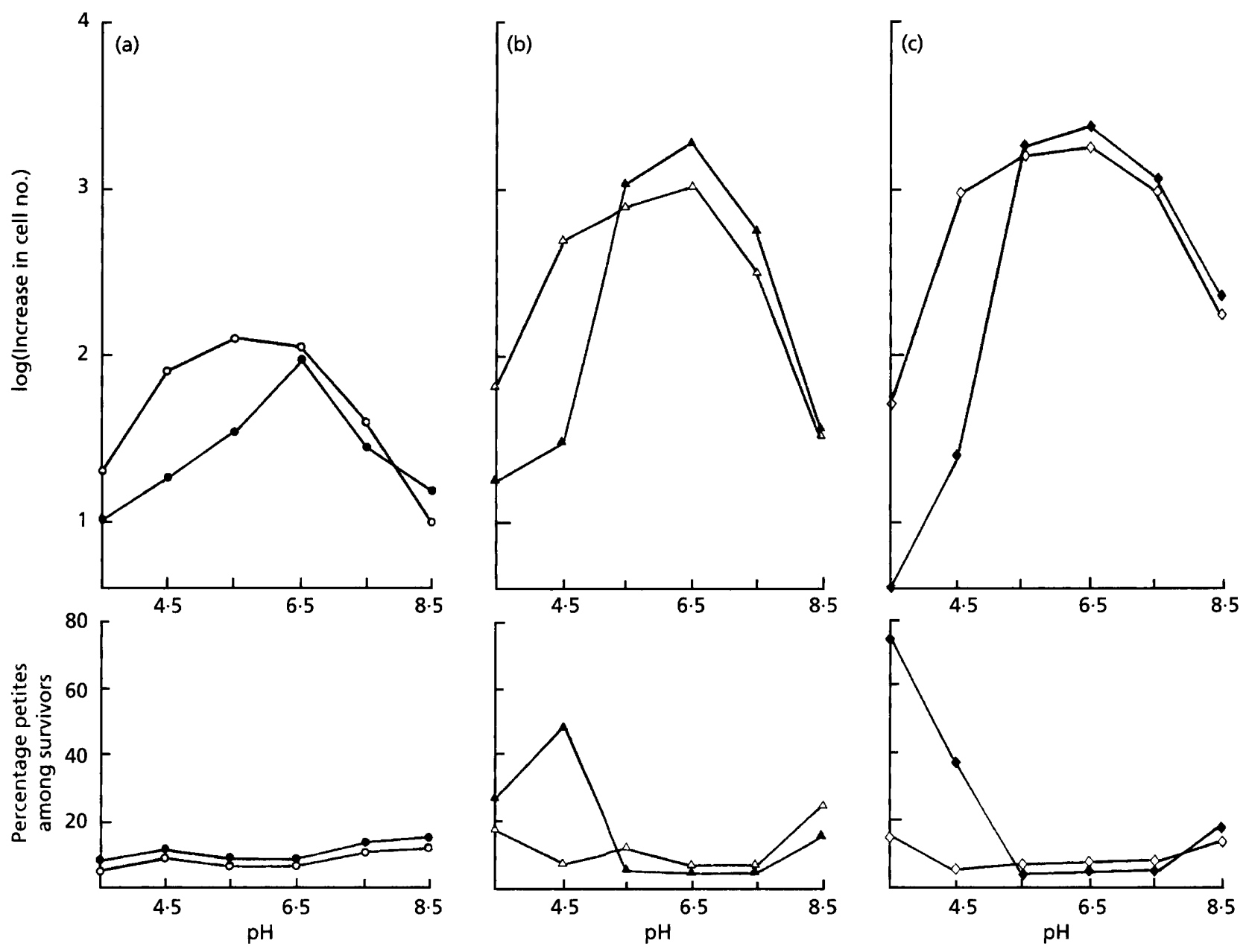

Fig. 4. Influence of the $\mathrm{pH}$ of a pre-incubation in buffered SD medium, and also the presence and absence of sorbate, on thermotolerance. SUB62 cells were grown to early exponential phase $\left(5 \times 10^{6}\right.$ cells $\left.\mathrm{ml}^{-1}\right)$ on pH 6.8 YPD medium at $25^{\circ} \mathrm{C}$. They were then centrifuged and resuspended in buffered $0.5 \times \mathrm{SD}$ medium at $\mathrm{pH} 3.5,4.5,5.5,6.5,7.5$ or 8.5 (see Methods) either without (open symbols) or with (filled symbols) $9 \mathrm{mM}$ sorbic acid. After pre-incubation in these buffered media for $5 \mathrm{~min}$ at $25^{\circ} \mathrm{C}$ (a), $1 \mathrm{~h}$ at $25^{\circ} \mathrm{C}$ (b) or $1 \mathrm{~h}$ at $38^{\circ} \mathrm{C}$ (c) cultures were immediately heated for $5 \mathrm{~min}$ at $50^{\circ} \mathrm{C}$ and then chilled. Survival was measured as ability to form colonies on plates at $28^{\circ} \mathrm{C}$, relative to the survival of the original pH 6.8 YPD starter culture given an identical $5 \mathrm{~min} 50^{\circ} \mathrm{C}$ heat stress. The percentage of survivors of heat stress in (a)-(c) that were respiratory-deficient petites is indicated below the thermotolerance data.

conditions (Fig. 1) revealed that major heat shock proteins had been induced in all the $39^{\circ} \mathrm{C}$ cultures, with the exception of the $\mathrm{pH} 4.5$ culture heat shocked in the presence of sorbate. Proteins pulse-labelled at $39^{\circ} \mathrm{C}$ in this $\mathrm{pH} 4.5$ culture appeared similar to those labelled at $25^{\circ} \mathrm{C}$ (Fig. 1). The block to heat shock protein expression in these cells was therefore not the result of a total inhibition of protein synthesis, suggesting that sorbate may be acting to selectively inhibit heat shock gene expression. Inhibition of the heat induction of heat shock proteins in $\mathrm{pH} 4.5$ cultures, but not $\mathrm{pH} 7.5$ cultures, was also obtained in a similar pulse-labelling experiment in which $3 \mathrm{mM}$ or $6 \mathrm{mM}$ potassium benzoate was employed in place of sorbate (Fig. 2). When sorbate or benzoate was present at concentrations of $1 \mathrm{mM}$ or less the inhibition of heat shock protein induction in $\mathrm{pH} 4.5$ cultures was only partial (data not shown).

\section{Effects of sorbate and culture pH on the activity of a heat shock element (HSE)-lacZ fusion}

Heat induction of many S. cerevisiae heat shock genes is due to the same HSE promoter sequence as is used in higher eukaryotes, a series of repeating units of the $5 \mathrm{bp}$ sequence $\mathrm{nGAAn}$, arranged in alternating orientations at each half-turn of the DNA helix (Sorger, 1991). This HSE is the binding site for the well-characterized yeast heat shock factor, a trimeric trans-activator of transcription which is needed at all growth temperatures but which increases its activity in response to temperature upshift (Sorger, 1990, 1991).

The optimum temperature for induction of HSE sequences in S. cerevisiae is $39^{\circ} \mathrm{C}$ (Sorger \& Pelham, 1987; Kirk \& Piper, 1991). Using cells carrying a plasmidborne E. coli lacZ gene under HSE control (transformant 

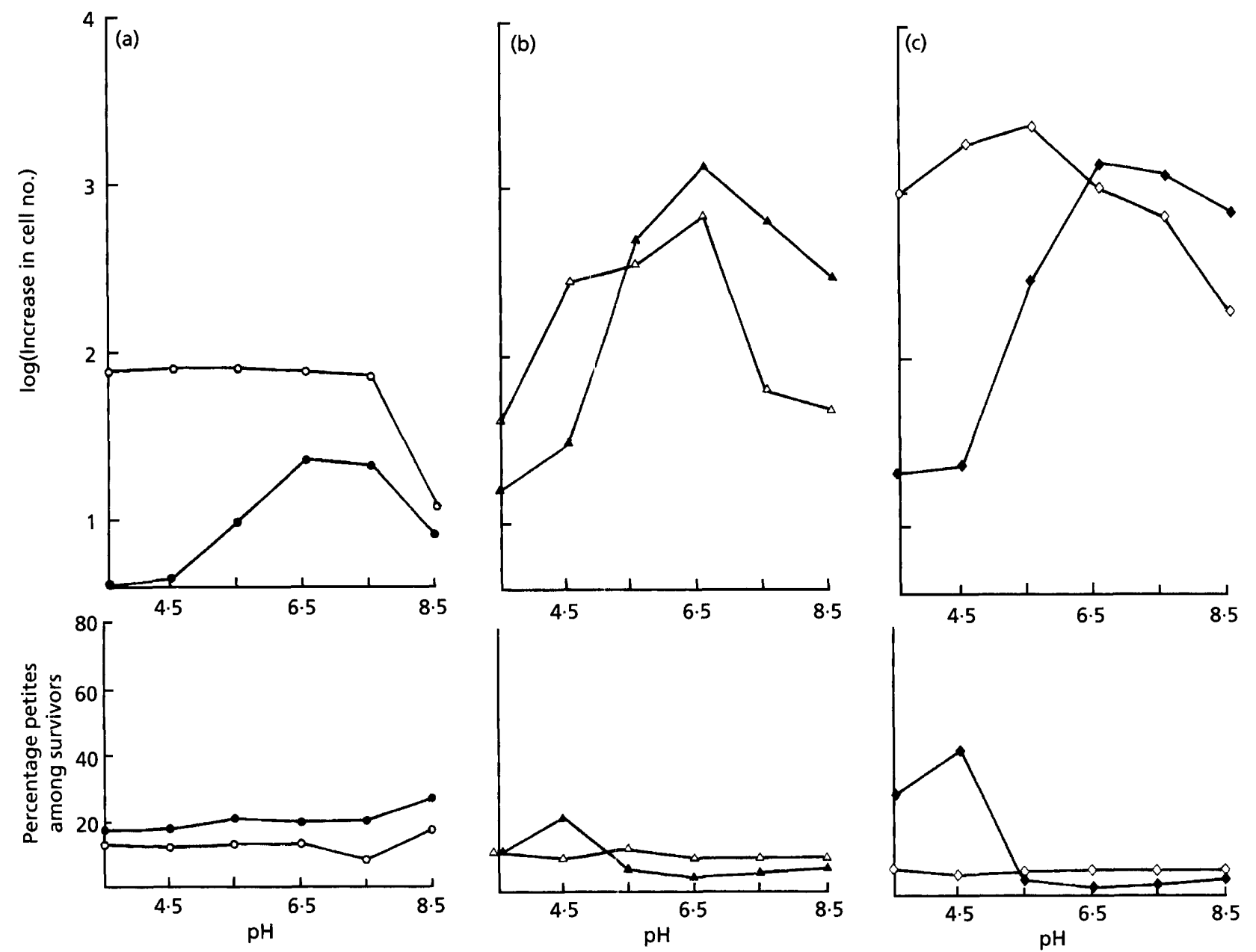

Fig. 5. Influence of the pH of a pre-incubation in YPD medium, and also the presence and absence of sorbate, on thermotolerance. Cells were grown to early exponential phase $\left(5 \times 10^{6}\right.$ cells ml $\left.{ }^{-1}\right)$ on pH 6.8 YPD medium at $25^{\circ} \mathrm{C}$. They were then centrifuged and resuspended in YPD previously adjusted to $\mathrm{pH} 3.5,4.5,5.5,6.5,7.5$ or 8.5, either without (open symbols) or with (filled symbols) $9 \mathrm{mM}$ sorbic acid. After pre-incubation for $5 \mathrm{~min}$ at $25^{\circ} \mathrm{C}$ (a), $1 \mathrm{~h}$ at $25^{\circ} \mathrm{C}$ (b) or $1 \mathrm{~h}$ at $38^{\circ} \mathrm{C}$ (c) cultures were immediately heated for $5 \mathrm{~min}$ at $50^{\circ} \mathrm{C}$ and then chilled. Survival is given relative to the survival of the original YPD starter culture given an identical heat stress. The percentage of the survivors that were respiratorydeficient petites is indicated in the lower panels.

SUB62-pHSE2; see Methods), the influences of medium $\mathrm{pH}$ and of sorbate on both basal and heat-induced levels of HSE activity were investigated (Fig. 3a). The low basal HSE-lac $Z$ expression in the absence of heat stress was unaffected by either culture $\mathrm{pH}$ or the presence of sorbate (Fig. 3a). Sorbate is therefore not a HSE inducer. Heatinduced HSE-lac Z expression in the absence of sorbate was influenced by the $\mathrm{pH}$ of the culture, being maximal at pH 6.5 and less at higher or lower pH (Fig. 3a). Sorbate caused this heat-induced $\beta$-galactosidase expression to be dramatically suppressed at low $\mathrm{pH}$. Sorbic acid $(1 \mathrm{mM})$ inhibited induction when the culture $\mathrm{pH}$ was below 6.0 and $9 \mathrm{mM}$ sorbic acid inhibited when culture $\mathrm{pH}$ was below 7.0. In contrast, sorbate had relatively little effect on HSE-lac $Z$ expression at higher $\mathrm{pH}$ values (Fig. 3a). This indicates that the sorbate inhibition of the heat shock response (Figs 1 and 2) occurs through a block to the heat induction of the HSE sequence of heat shock gene promoters.

\section{Effects of sorbate and external pH on thermotolerance}

An increased thermotolerance is one of the major consequences of a mild sublethal heat shock (see Introduction). To investigate the effects of sorbate and external $\mathrm{pH}$ on thermotolerance, cells were transferred to media of different $\mathrm{pH}$ for either 5 or $60 \mathrm{~min}$ at $25^{\circ} \mathrm{C}$, or $60 \mathrm{~min}$ at $38^{\circ} \mathrm{C}$, either without preservative or in the presence of $9 \mathrm{mM}$ sorbate. They were then subjected to a potentially lethal heat treatment $\left(50^{\circ} \mathrm{C}, 5 \mathrm{~min}\right)$ without change to medium $\mathrm{pH}$ or sorbate level (Figs 4 and 5). Their survival of lethal heat stress in the absence of sorbate showed that thermotolerance was influenced by 
the external $\mathrm{pH}$ during lethal heat treatment. This was irrespective of whether they were on complex medium (YPD; Fig. 4) or defined medium (SD; Fig. 5), and whether $\mathrm{pH}$ preconditioning had been at $25^{\circ} \mathrm{C}$ or $38^{\circ} \mathrm{C}$. This effect of medium $\mathrm{pH}$ on thermotolerance is not unexpected, since external $\mathrm{pH}$ is known to influence $\mathrm{pH}_{\mathrm{i}}$ even in unstressed cells (Borst-Pauwells, 1981). The $\mathrm{pH}$ of heating affects thermotolerance, tolerance being maximal at a $\mathrm{pH}$ approximating to physiological $\mathrm{pH}_{\mathrm{i}}$ values $(6-7)$ and considerably lower at extremes of pH (Figs 4 and 5). This probably reflects a lowered disturbance to homeostasis when cells are heated at physiological $\mathrm{pH}$ values.

Figs 4 and 5 also reveal that $9 \mathrm{mM}$ sorbate exerted strongly $\mathrm{pH}$-dependent effects on thermotolerance. At higher $\mathrm{pH}$ values, it caused small increases in thermotolerance whereas at low $\mathrm{pH}$ it had the converse effect, reducing thermotolerance and preventing the usual thermotolerance increases with a $38^{\circ} \mathrm{C}$ pre-incubation. A brief heat treatment at a potentially lethal temperature $\left(50^{\circ} \mathrm{C}\right)$, when applied at low $\mathrm{pH}$ in conjunction with the presence of sorbate, was found to strongly induce respiratory-deficient petites. Such petites were a substantial fraction of the survivors of $\mathrm{pH} 4.5$ cultures heated in the presence of $9 \mathrm{mM}$ sorbate (see lower panels; Figs 4 and 5). It is well-established that $S$. cerevisiae cultures, when briefly heated at a potentially lethal temperature or grown at supraoptimal temperatures $\left(37-39^{\circ} \mathrm{C}\right)$, accumulate a greater proportion of their cells as respiratorydeficient petites (Van Uden, 1984). This is thought to reflect sensitivity of the mitochondria to heat damage. Figs 4 and 5 indicate that this damage is enhanced considerably by the presence of intracellular sorbic acid, an effect more pronounced in low $\mathrm{pH}$ cultures due to the higher uptake of acid by the cells of these cultures (see Introduction).

The experiment in Fig. 5(b, c) was repeated, but changing the procedure such that cells were transferred to sorbatefree medium of a single, defined $\mathrm{pH}$ immediately after the $1 \mathrm{~h}$ incubation at $25^{\circ} \mathrm{C}$ or $38^{\circ} \mathrm{C}$ in media of different $\mathrm{pH}$ and prior to the $50^{\circ} \mathrm{C} 5$ min lethal heat treatment (Fig. 6). Survival of the cells heated in the absence of sorbate shows the well-established thermotolerance induction with mild heat $\left(38^{\circ} \mathrm{C}\right)$ pretreatment (compare Fig. 6a, b). Also it reveals that the $\mathrm{pH}$ of pre-incubation does not have a marked effect on thermotolerance, the $\mathrm{pH}$ of lethal heating being relatively much more important (compare Fig. 6a, b with $5 \mathrm{~b}, \mathrm{c}$ ). Pretreatment at $25^{\circ} \mathrm{C}$ of higher $\mathrm{pH}$ cultures with sorbate increased thermotolerance (Fig. 6a). Sorbate is therefore a chemical inducer of thermotolerance at bigher $\mathrm{pH}$. However, $25^{\circ} \mathrm{C}$ sorbate treatment at lower $\mathrm{pH}$ caused relatively little thermotolerance change (Fig. 6a). Pretreatment with both mild heat $\left(38^{\circ} \mathrm{C}\right)$ and sorbate at higher $\mathrm{pH}$ values increased thermotolerance only slightly above the values achievable with heat shock alone, while sorbate largely prevented the normal increase in thermotolerance with sublethal beat at lower $p H$ (Fig. 6b). The removal of sorbate prior to lethal heating eliminated the strong selection of petites seen in Figs 4 and 5 , less than $5 \%$ of the survivors of lethal heating in Fig. 6 being petites irrespective of the $\mathrm{pH}$ of pre-incubation (not shown).
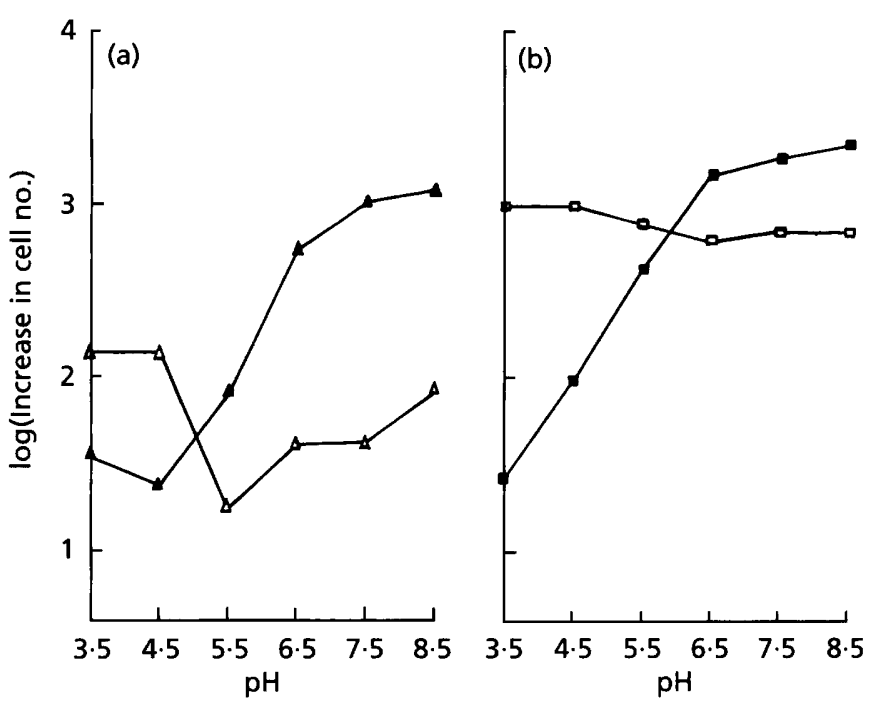

Fig. 6. Influences of sorbate pretreatment and pre-incubation $\mathrm{pH}$ on thermotolerance, when the subsequent lethal heating was conducted at a single defined $\mathrm{pH}$ and in the absence of sorbate. Cells were grown to early exponential phase $\left(5 \times 10^{6}\right.$ cells $\mathrm{ml}^{-1}$ ) on $\mathrm{pH} 6.8 \mathrm{YPD}$ medium at $25^{\circ} \mathrm{C}$. They were then centrifuged and resuspended in YPD previously adjusted to pH 3.5, 4.5, 5.5, 6.5, 7.5 or 8.5 (see Methods) either without (open symbols) or with (filled symbols) $9 \mathrm{mM}$ sorbic acid. After pre-incubation for $1 \mathrm{~h}$ at either $25^{\circ} \mathrm{C}$ (a) or $38^{\circ} \mathrm{C}(\mathrm{b})$ at these $\mathrm{pH}$ values, cultures were harvested by centrifugation, resuspended in $\mathrm{pH} 6.0$ sorbate-free YPD, immediately heated for $5 \mathrm{~min}$ at $50{ }^{\circ} \mathrm{C}$ and then chilled. Survival is indicated relative to the survival of the original YPD starter culture given an identical heat stress.

\section{Effects of the petite mutation on heat shock protein induction and on the activity of a HSE-lacZ fusion}

We have observed that petites derived from $S$. cerevisiae strain SUB62 (whether spontaneous or sorbic-acidinduced) are capable of fermentative growth at low $\mathrm{pH}$ in the presence of concentrations of sorbic acid that totally inhibit the growth of respiration-competent cells. On $\mathrm{pH} 4.5$ YPD plates petites are capable of slow growth in the presence of $4.5 \mathrm{mM}$ sorbic acid, whereas the growth of respiration-competent cells becomes totally inhibited when sorbic acid exceeds approximately $1 \mathrm{mM}$ (data not shown). The small proportion of petites in $S$. cerevisiae SUB62 cultures can therefore be selected as the only cells capable of appreciable growth on $\mathrm{pH} 4.5$ plates containing $4.5 \mathrm{mM}$ sorbate. Adaption to $\mathrm{pH} 4.5$ fermentative growth at this concentration of weak acid preservative therefore involves selective outgrowth of the growth-arrested respiration-competent cells by the petites which are always present as a small proportion of the cells of $S$. cerevisiae cultures.

Millimolar concentrations of sorbate and benzoate inhibit both growth and the heat shock response (Figs 1, 2 and 3a) of respiration-competent cells at low $\mathrm{pH}$. We were therefore intrigued to know whether such concentrations caused a similar inhibition of heat shock gene expression in the more sorbate-resistant petites derived from these cultures. At the lowest $\mathrm{pH}$ at which cultures of petites 


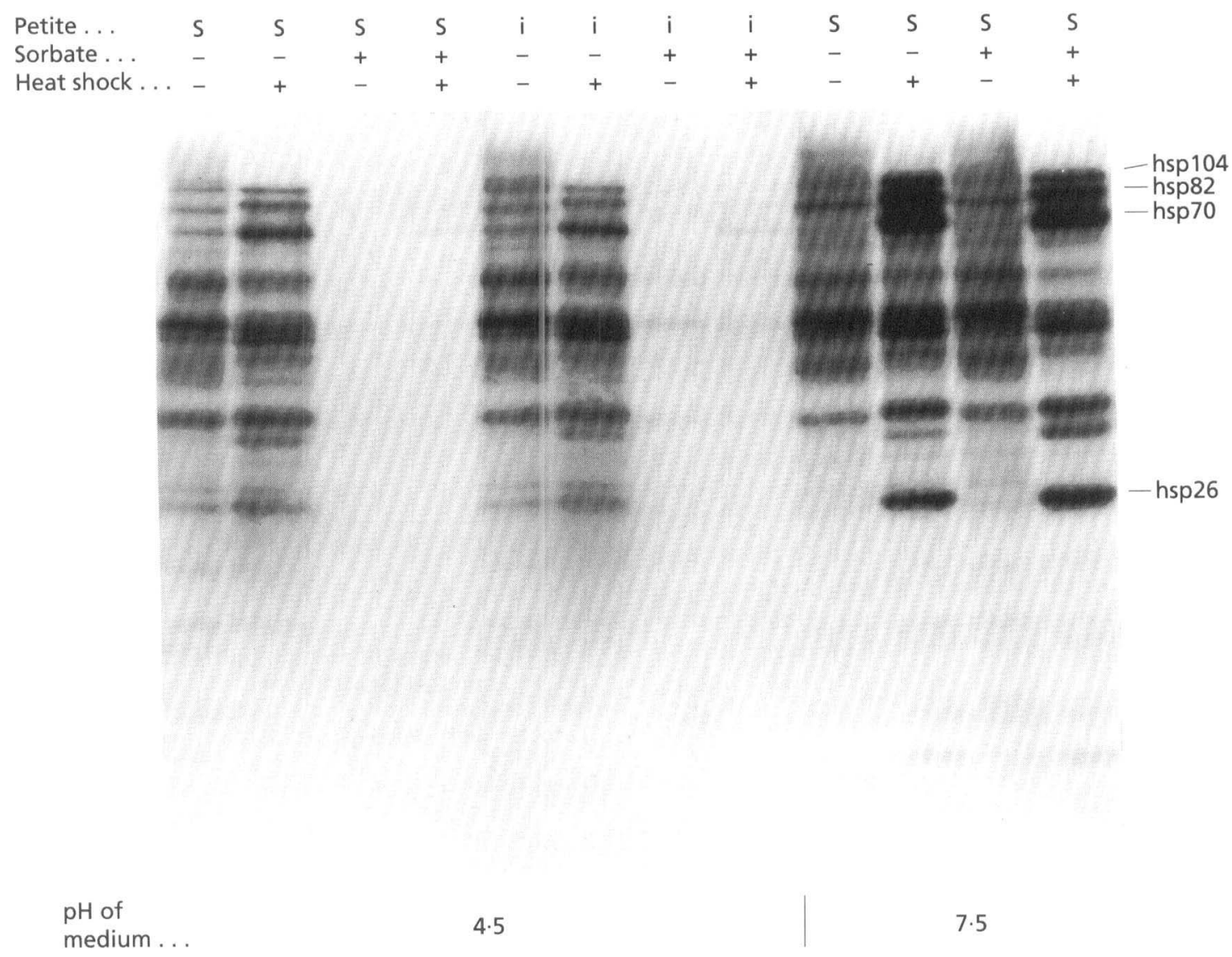

Fig. 7. The petite mutation restores the capacity for synthesis of heat shock proteins in low pH cultures. Cells of a spontaneous petite derived from strain SUB62 (S) were resuspended in medium buffered at pH 4.5 or 7.5 ; also, cells of a petite derived by heating SUB62 in the presence of sorbic acid (i) were resuspended at $\mathrm{pH} 4.5$. The cultures were then labelled with $\left[{ }^{3} \mathrm{H}\right]$ leucine for $40 \mathrm{~min}$ either at $25^{\circ} \mathrm{C}$ or immediately after heat shock to $39{ }^{\circ} \mathrm{C}$ in the presence and absence of $9 \mathrm{mM}$ sorbic acid. Major heat shock proteins are indicated to the right of the figure.

could incorporate labelled amino acid into protein $(\mathrm{pH} 4.5)$ the presence of $9 \mathrm{mM}$ sorbate reduced incorporation of $\left[{ }^{3} \mathrm{H}\right]$ leucine into protein (Fig. 7). However, both a spontaneous petite and a petite induced by heating a SD medium culture in the presence of sorbate (Fig. 4b) showed detectable heat induction of heat shock proteins at $\mathrm{pH} 4.5$ in the presence of sorbate (Fig. 7). Also a petite displayed limited heat-inducibility of a HSE-lac Z fusion in $\mathrm{pH} 5 \cdot 0,5 \cdot 5$ or $6 \cdot 0$ cultures heat shocked in the presence of $9 \mathrm{mM}$ sorbate (Fig. 3b, c), irrespective of whether it had been cultured on SD medium for several generations in the absence (Fig. 3b) or the presence (Fig. 3c) of $1 \mathrm{mM}$ sorbate. It remains to be seen whether this partial recovery of a heat shock response in low $\mathrm{pH}$ sorbate-trcated cultures of petites contributes to the greater capacity of petites for fermentative growth in the presence of this preservative.

\section{Other inhibitors of heat shock protein induction in yeast}

Prior to this study only flavonoids had been shown to be selective inhibitors of the heat shock response (see Introduction), acting to block heat shock protein ex- pression in mammalian cells (Hosokawa et al., 1990). A flavonoid (quercetin) was tested to see whether it would act, like sorbic and benzoic acids (Figs 1 and 2), to inhibit heat shock protein induction in yeast. By protein pulselabelling, as in Figs 1, 2 and 7, the addition of $50 \mu \mathrm{m}$ or $200 \mu \mathrm{m}$ quercetin to $\mathrm{pH} 4 \cdot 5$ and $\mathrm{pH} 7 \cdot 5 \mathrm{~S}$. cerevisiae cultures was found not to influence heat shock protein induction by heat shock (data not shown). It is possible that this result reflects a lack of permeability of yeast cells to quercetin, a point that was not investigated further.

The rapid $\mathrm{pH}_{\mathrm{i}}$ decline due to weak acid preservatives (see Introduction) is a possible cause of sorbate- and benzoatetreated cultures of low $\mathrm{pH}$ being unable to mount a response to heat shock (Figs 1 and 2). Maintenance of $\mathrm{pH}_{\mathrm{i}}$ in yeast largely occurs through plasma-membraneATPase-catalysed protein extrusion and the excretion of organic acids (Serrano, 1991). We have previously shown that a mutant with reduced plasma-membrane ATPase activity shows reduced heat shock protein induction by heat shock (Panaretou \& Piper, 1990). We therefore tested an inhibitor of plasma membrane ATPase as a possible inhibitor of the heat shock response. This inhibitor, diethylstilboestrol, is known to hypersensitize 


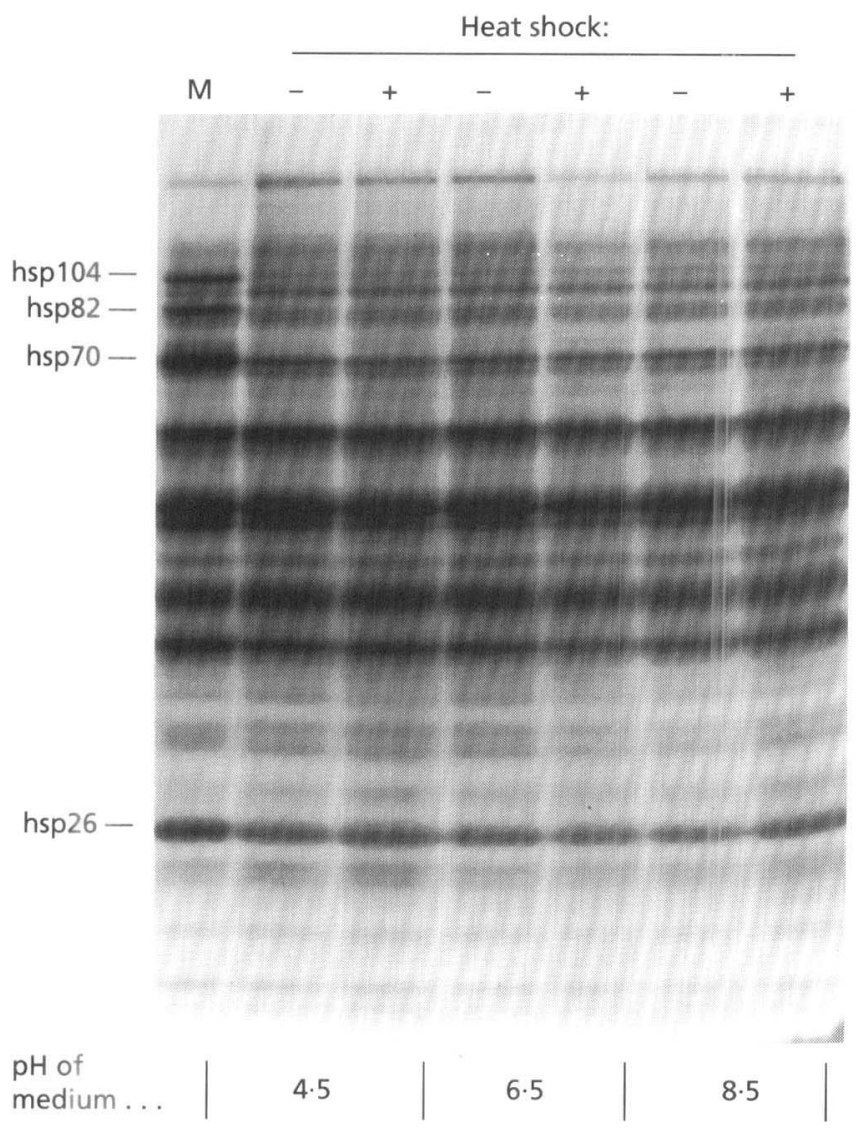

Fig. 8. Diethylstilboestrol, a plasma-membrane-ATPase inhibitor, inhibits heat induction of heat shock proteins. SUB62 cells were transferred to SD medium buffered to $\mathrm{pH} 4.5,6.5$ or 8.5. Diethylstilboestrol $\left(50 \mu \mathrm{g} \mathrm{ml}^{-1}\right)$ was added immediately before addition of labelled leucine. Labelling was for $\mathbf{4 0}$ min, either at $25^{\circ} \mathrm{C}(-)$ or immediately after heat shock to $39^{\circ} \mathrm{C}$ $(+)$. For the labelling of the control cells not subject to diethylstilboestrol treatment see Fig. 1. $M$ is a marker track containing a sample of the proteins normally labelled in yeast at $39^{\circ} \mathrm{C}$.

yeast to thermal death (Coote et al., 1991). When used at a concentration $(50 \mu \mathrm{m})$ that totally inhibits plasmamembrane-ATPase action (Coote et al., 1991) it rapidly rendered cells incapable of a heat shock response, diethylstilboestrol-treated cells displaying no alteration in their protein synthesis pattern with heat shock to $39{ }^{\circ} \mathrm{C}$ (Fig. 8). However, this inhibitory action differed from that caused by sorbic and benzoic acids in being apparently independent of external $\mathrm{pH}$ (compare Fig. 1 with Fig. 8).

Another way to cause a decline in $\mathrm{pH}_{\mathrm{i}}$ in low $\mathrm{pH}$ fermentative cultures is to add an uncoupler such as 2,4 dinitrophenol or CCCP. Uncouplers cause membrane depolarization. They differ from sorbic and benzoic acids in that they permeate membranes in both their dissociated and protonated states with the result that uncouplers, unlike these preservatives, do not show pronounced intracellular concentration when $\mathrm{pH}_{\mathrm{i}}$ values are higher than the extracellular $\mathrm{pH}$. In $\mathrm{pH} 4.5$ cultures $75 \mu \mathrm{M}$ CCCP abolished heat induction of heat shock proteins, while $50 \mu \mathrm{M}$ CCCP caused a greatly reduced induction of these proteins (Fig. 9). This inhibition was not evident at $\mathrm{pH} 7.5$ (Fig. 9). The concentrations of CCCP which were effective in inhibiting the heat shock response were considerably lower than the concentrations of sorbate or benzoate needed for similar levels of inhibition (data not shown). These results with weak acid preservatives, diethylstilboestrol and CCCP suggest that a substantial drop in $\mathrm{pH}_{\mathbf{i}}$ and/or depolarization of the plasma membrane may prevent yeast cultures from mounting a heat shock response.

\section{DISCUSSION}

\section{Weak acids block HSE induction in low pH cultures}

This study has shown that weak acid preservatives inhibit the normal induction of major heat shock proteins in low $\mathrm{pH}$ cultures by heat shock (Figs 1 and 2). Measurements of HSE-lacZ activity (Fig. 3) show this to be due to lack of induction of the HSE promoter sequence. This inhibition of the heat shock response may reflect the depression of $\mathrm{pH}_{\mathrm{i}}$ that weak acids cause, since a similar inhibition is also seen with uncouplers (Fig. 9) and an inhibitor of plasma-membrane ATPase (Fig. 8). It is an inhibition partially suppressed by respiratory deficiency (Figs 3 and 7).

Even though weak acids inhibit beat induction of the heat shock response in acidified yeast cultures, we find that they also act as chemical inducers of certain heat shock genes in the same cells. Northern blot analysis of heat shock gene mRNAs has shown that the mRNAs for HSP30, HSP2 6 and HSP12 are all induced at $25^{\circ} \mathrm{C}$ in the absence of beat shock after cells are treated with the concentrations of sorbate, benzoate and CCCP shown in this paper to inhibit the response to heat shock (unpublished results). Not all heat shock genes are induced under these conditions. Also, since the HSE promoter sequence is not induced by sorbate treatment at any medium pH (Fig. 3), another promoter element must be involved in these inductions of heat shock mRNAs at $25^{\circ} \mathrm{C}$. Recently, an upstream activator (UAS) element unrelated to the HSE was demonstrated to cause the activation of the CTT1 gene in response to a variety of stresses, including heat shock, osmotic stress, oxidative stress and nitrogen starvation (Marchler et al,, 1993). This alternative heat shock promoter element is one possible candidate for the sequence directing heat shock gene induction by weak acids in the absence of heat stress.

\section{Weak acid preservatives and uncouplers may inhibit the heat shock response by lowering $\mathrm{pH}_{\mathrm{i}}$}

Weak acid preservatives differ from weak acid uncouplers in that the former cross membranes readily only when undissociated, while uncouplers are lipophilic in both their protonated and unprotonated forms. Sorbate and benzoate will therefore concentrate inside cells and lower $\mathrm{pH}_{\mathrm{i}}$ in response to a higher $\mathrm{pH}$ on the cytosolic side of the cell membrane (see Introduction) while uncouplers, in contrast, will depolarize membranes (Thevelein et al., 1987) but not concentrate in the cytosol. Weak acid preservatives and uncouplers also have very different 


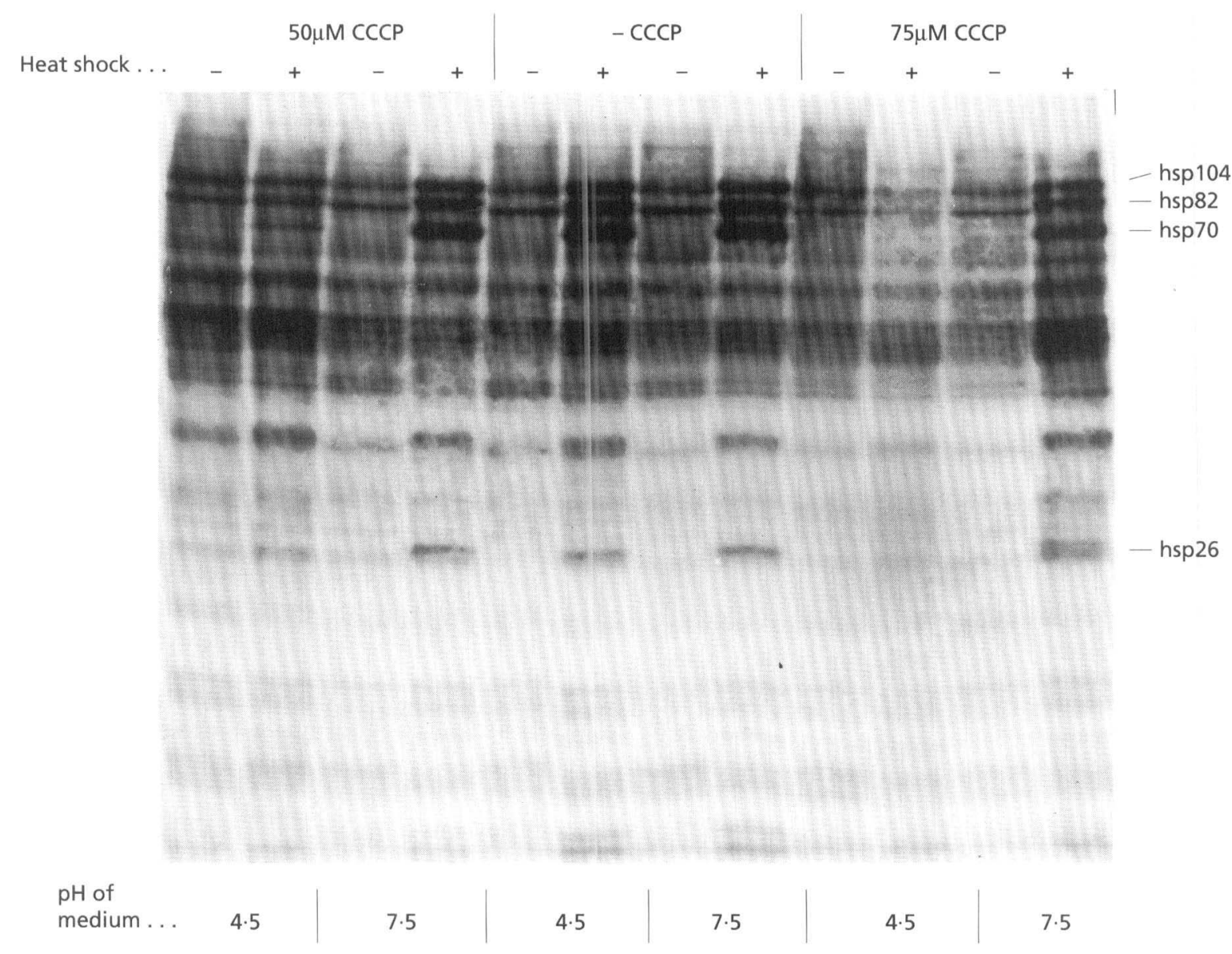

Fig. 9. An uncoupler (CCCP) inhibits heat induction of heat shock proteins in low pH cultures. S. cerevisiae cells were incubated with $\left[{ }^{3} \mathrm{H}\right]$ leucine for $40 \mathrm{~min}$ either at $25^{\circ} \mathrm{C}(-)$ or after heat shock to $39{ }^{\circ} \mathrm{C}(+)$ in the absence and presence of CCCP. They had previously been resuspended in medium buffered at pH 4.5 or 7.5 as in Methods. At $75 \mu \mathrm{M}$, CCCP appears to cause a total inhibition of heat shock protein induction, whereas $50 \mu \mathrm{M} \mathrm{CCCP}$ produces more partial inhibition.

effects on yeast glycolytic flux. In low $\mathrm{pH}$ cultures preservatives inhibit (Krebs et al., 1983; Francois et al., 1986) while uncouplers stimulate glycolysis (see Francois et al., 1986, 1988a, b, for literature).

In this study we have observed that weak acid preservatives (sorbate and benzoate) and an uncoupler (CCCP) have similar inhibitory effects on the response of low $\mathrm{pH}$ yeast cultures to heat shock (Figs 1,2 and 9). It is improbable therefore that these inhibitions are linked to the dramatically opposite effects of these agents on glycolytic flux. Instead, they are more likely to reflect the common action of preservatives and uncouplers in causing $\mathrm{pH}_{\mathrm{i}}$ decline in low $\mathrm{pH}$ cultures. The electrochemical gradient at the yeast plasma-membrane, largely established and maintained through the action of plasmamembrane ATPase (Serrano, 1991), is essential for nutrient uptake, maintenance of potassium balance and regulation of $\mathrm{pH}_{\mathrm{i}}$. The action of this ATPase also has a strong influence over the thermotolerance of $S$. cerevisiae and Schizosaccharomyces pombe (Panaretou \& Piper, 1990; Coote et al., 1991 ; Piper, 1993; Coote, 1993) and influences the ability of $S$. cerevisiae cells to synthesize heat shock proteins in response to heat shock. A mutation which reduces ATPase activity ( $p m a 1.1$ ) results in both a lowered $\mathrm{pH}_{\mathrm{i}}$ (Ulazewski et al., 1987) and reduced induction of heat shock proteins with heat shock (Panaretou \& Piper, 1990). The similarities of uncouplers and weak acid preservatives in preventing a response to heat shock in low $\mathrm{pH}$ cultures (Figs 1,2 and 9) might reflect their common action in reducing $\mathrm{pH}_{\mathrm{i}}$. Consistent with this, the plasma-membrane ATPase inhibitor diethylstilboestrol rapidly rendered cells incapable of a heat shock response even though their capacity for protein synthesis was not lost (Fig. 8). While the results in Figs $1-3,8$ and 9 are largely consistent with lowered $\mathrm{pH}_{\mathrm{i}}$ preventing a response to heat shock, there may be other explanations for our results, including the direct inhibition of a stresssignalling pathway by the various chemical agents that we have employed.

\section{The effects of sorbate on thermotolerance}

Prior to this study N. Van Uden had reported that sorbate has no effect on the thermotolerance of $S$. cerevisiae, but shifts the Arrhenius plots and $T_{\max }$ of growth to lower 
temperatures (Van Uden, 1984). It is difficult to assess this study as the conditions, notably $\mathrm{pH}$, of growth were not reported. Coote et al. (1991) showed thermotolerance increasing during a $9 \mathrm{mM}$ sorbic acid treatment, both at $\mathrm{pH} 4.5$ and at $\mathrm{pH} 6.0$. However, a partial thermotolerance increase was also seen in cells exposed to $\mathrm{pH} 4.5$ in the absence of sorbate. In their study, Coote et al. (1991) conducted lethal heating after resuspending the cells in sorbate-free medium of defined pH (as in Fig. 6 of this paper). Our results clearly show that a $25^{\circ} \mathrm{C}$ sorbate treatment at a $p H$ below about 5.5 slightly reduces thermotolerance (Fig. 6a) and also that sorbate prevents the usual thermotolerance increase with sublethal heat treatment (Fig. 6b). However, in cultures of $p H$ values above about 5.5 sorbate acts as a strong chemical inducer of thermotolerance even at $25^{\circ} \mathrm{C}$ (Fig. 6a), there being little additional increase in thermotolerance when this treatment is carried out at a heat stress temperature $\left(38{ }^{\circ} \mathrm{C}\right.$; Fig. 6b). Figs 4 and 5 show the $\mathrm{pH}$ of lethal heating exerting an appreciable influence on basal $\left(25^{\circ} \mathrm{C}\right)$ and sublethal heat-induced thermotolerance levels in the absence of sorbate. They also reveal the strong influence that medium $\mathrm{pH}$ exerts over the effects of sorbate on thermotolerance.

\section{Heating low pH cultures with sorbate selects cytoplasmic petites}

Upon entry to yeast cells sorbate concentrates within mitochondria, causing pronounced disruption of mitochondrial structure (Cole, 1987). Heating in the presence of sorbate strongly induces petites (Figs 4 and 5) indicating that this sorbate-induced damage to mitochondria is enhanced considerably by heat. This effect is probably more pronounced in low $\mathrm{pH}$ cultures because the acid penetrates cells more effectively in such cultures (see Introduction). Also, it occurs in glucose-grown $S$. cerevisiae in which mitochondrial functions are repressed. However, mitochondrial repression is never absolute and even on high sugar substrates respiration can provide as much as $34 \%, 48 \%$ and $88 \%$ of the total ATP yield during the aerobic fermentation of glucose, maltose and galactose respectively (Lagunas, 1986).

\section{Possible reasons for the higher resistance of petites to growth in the presence of sorbate}

The higher sorbate resistance of petites is unlikely to be due to the loss of any residual respiratory activity present in glucose-repressed cells. While weak acids inhibit respiration in S. cerevisiae, they also cause an inhibition of fermentation (Krebs et al., 1983; Francois et al., 1986, $1988 \mathrm{a}, \mathrm{b})$. In the more preservative-tolerant $Z$. bailii long-term adaptation to growth in the presence of weak acids involves a switch from a predominantly aerobic to a predominantly anaerobic metabolism, millimolar amounts of preservative causing almost immediate inhibition of oxidative respiration in $Z$. bailii yet, unlike in $S$. cerevisiae, practically no inhibition of fermentation (Cole, 1987; Cole \& Keenan, 1987).

It has been proposed that the adaption of $Z$. bailii to growth in the presence of weak acids involves the induction of an energy-requiring system for extrusion of the acid (Warth, 1978, 1988). While such active extrusion has not yet been discounted, it would probably be futile in conferring resistance since concentration of benzoate by $Z$. bailii cells is exactly as would be predicted from considerations of $\mathrm{pH}_{\mathrm{i}}$ and the $\mathrm{pK}$ of the acid (Cole \& Keenan, 1986, 1987). Instead, increases in plasmamembrane-ATPase-catalysed proton extrusion and a decreased protoplast volume undoubtedly contribute to maintaining the $\mathrm{pH}_{\mathrm{i}}$ of $Z$. bailii cells that have adapted to growth in the presence of weak acids (Cole \& Keenan, 1987). In addition, the PFK1 of $Z$. bailii shows less dramatic inhibition in response to $\mathrm{pH}_{\mathrm{i}}$ depression (Cole, 1987) as compared to the PFK1 of S. cerevisiae (Krebs et al., 1983; Francois et al., 1986). This may better equip Z. bailii to maintain glycolytic flux in the presence of $\mathrm{pH}_{\mathrm{i}^{-}}$ depressing amounts of weak acids.

There is no evidence to indicate that adaption of yeasts to growth in the presence of weak acids can occur through reduced acid entry, the result of a permeability barrier at the cell membrane. However, uptake of certain molecules by S. cerevisiae is partly controlled by the functional state of mitochondria. Conversion of cells to petites, or treatment with inhibitors affecting mitochondrial function and biogenesis, causes deficiencies in the utilization of galactose, maltose and $\alpha$-methyl-D-glucoside that are the result of reduced uptake of these sugars (Evans \& Wilkie, 1976; Mahler \& Wilkie, 1978). Also, the mitochondrial genome of $S$. cerevisiae controls cell permeation by several cytotoxic drugs, petites being considerably more resistant to killing by these agents (Mahler \& Wilkie, 1978; L. Cheng \& D. Wilkie, unpublished results). It will be interesting to determine if the enhanced resistance of $S$. cerevisiae petites to growth in the presence of weak acids has the same genetic basis. It will also be interesting to determine if this enhanced resistance is associated with the partial recovery of a response to heat shock in preservative-treated petite cultures of low pH (Figs 3 and 7).

\section{ACKNOWLEDGEMENTS}

We thank Martin Cole and David Wilkie for their advice and stimulating discussions. This work was supported by SERC grant GR/F72932.

\section{REFERENCES}

Ananthan, J., Goldberg, A. L. \& Voellmy, R. (1985). Abnormal proteins serve as eukaryotic stress signals and trigger the activation of heat shock genes. Science 232, 522-524.

Borst-Pauwels, G. W. G. H. (1981). Ion transport in yeast. Biochim Biophys Acta 650, 88-127.

Cole, M. B. (1987). The effect of weak acids and $p H$ on Zygosaccharomyces bailii. $\mathrm{PhD}$ thesis, University of East Anglia.

Cole, M. B. \& Keenan, M. J. H. (1986). Synergistic effects of weak acid preservatives and $\mathrm{pH}$ on the growth of Zygosaccharomyces bailii. Yeast 2, 93-100.

Cole, M. B. \& Keenan, M. J. H. (1987). Effects of weak acids and external $\mathrm{pH}$ on the intracellular $\mathrm{pH}$ of $Z$ ygosaccharomyces bailii, and its implications in weak-acid resistance. Yeast 3, 23-32. 
Coote, P. J. (1993). Mecbanisms of induced thermotolerance in Saccharomyces cerevisiae. PhD thesis, University of Nottingham.

Coote, P. J., Cole, M. B. \& Jones, M. V. (1991). Induction of increased thermotolerance in Saccharomyces cerevisiae may be triggered by a mechanism involving intracellular $\mathrm{pH}$. J Gen Microbiol 137, 1701-1708.

Evans, I. H. \& Wilkie, D. (1976). Mitochondrial factors in the utilisation of sugars in Saccbaromyces cerevisiae. Genet Res 27, 89-93.

Francois, J., Van Schaftingen, E. \& Hers, H.-G. (1986). Effect of benzoate on the metabolism of fructose 2,6-bisphosphate in yeast. Eur J Biochem 154, 141-145.

Francois, J., Van Schaftingen, E. \& Hers, H.-G. (1988a). Chatracterisation of phosphofructokinase 2 and of enzymes involved in the degradation of fructose 2,6-bisphosphate in yeast. Eur $J$ Biochem 171, 599-608.

Francois, J., Villanueva, M. E. \& Hers, H.-G. (1988b). The control of glycogen metabolism in yeast: interconversion in vivo of glycogen synthase and glycogen phosphorylase induced by glucose, a nitrogen source or uncouplers. Eur J Biochem 174, 551-559.

Hosokawa, N., Hirayoshi, K., Nakai, A., Hosokawa, Y., Marui, N., Yoshida, M., Sakai, T., Nishino, H., Aoike, A., Kawai, K. \& Nagata, K. (1990). Flavonoids inhibit the expression of heat shock proteins. Cell Struct Funct 15, 393-401.

Kirk, N. \& Piper, P. W. (1991). The determinants of heat shock element-directed lac $Z$ expression in Saccharomyces cerevisiae. Yeast $\mathbf{7}$. 539-546.

Krebs, H. A., Wiggins, D., Stubbs, M., Sols, A. \& Bedoya, F. (1983). Studies on the mechanism of the antifungal action of benzoate. Biochem J 214, 657-663.

Lagunas, R. (1986). Misconceptions about the energy metabolism of Saccharomyces cerevisiae. Yeast 2, 221-228.

Lindquist, S. \& Craig, E. A. (1988). The heat shock proteins. Annu Rev Genet 55, 1151-1191.

Mager, W. H. \& Moradas-Ferreira, P. (1993). Stress response of yeast. Biochem J 290, 1-13.

Mahler, H. R. \& Wilkie, D. (1978). Mitochondrial control of sugar utilisation in Saccharomyces cerevisiae. Plasmid 1, 125-133.

Marchler, G., Schuller, C., Adam, G. \& Ruis, H. (1993). A Saccharomyces cerevisiae UAS element controlled by protein kinase A activates transcription in response to a variety of stress conditions. EMBO J 12, 1997-2003.

Miller, J. H. (1972). Experiments in Molecular Genetics. Cold Spring Harbor, NY: Cold Spring Harbor Laboratory.

Panaretou, B. \& Piper, P. W. (1990). Plasma membrane ATPase action affects several stress tolerances of Saccharomyces cerevisiae and Scbizosaccharomyces pombe as well as the extent and duration of the heat shock response. J Gen Microbiol 136, 1763-1770.

Panaretou, B. \& Piper, P. W. (1992). The plasma membrane of yeast acquires a novel heat shock protein ( $\mathrm{Hsp} 30)$ and displays a decline in proton-pumping ATPase levels in response to both heat shock and the entry to stationary phase. Eur J Biochem 206, 635-640.

Piper, P. W. (1993). Molecular events associated with the acquisition of heat tolerance in the yeast Saccharomyces cerevisiae. FEMS Microbiol Rev 11, 339-356.

Russell, A. D. (1991). Mechanisms of bacterial resistance to nonantibiotics: food additives and food and pharmaceutical preservatives. J Appl Bacteriol 71, 191-201.

Serrano, R. (1991). Transport across yeast vacuolar and plasma membranes. In The Molecular Biology of the Yeast Saccharomyces. Genome Dynamics, Protein Synthesis, and Energetics, pp. 523-585. Edited by J. N. Strathern, E. W. Jones \& J. R. Broach. Cold Spring Harbor, NY: Cold Spring Harbor Laboratory.

Sorger, P. K. (1990). Yeast heat shock factor contains separable transient and sustained response transcriptional activators. Cell $\mathbf{6 2}$, 793-805.

Sorger, P. K. (1991). Heat shock factor and the heat shock response. Cell 65, 363-366.

Sorger, P. K. \& Pelham, H. R. B. (1987). Purification and characterisation of a heat-shock element binding protein from yeast. $E M B O$ J 6, 3035-3041.

Sherman, F., Fink, G. R. \& Hicks, J. B. (1983). Synthetic complete medium. In Methods in Yeast Genetics, pp. 62-84. Cold Spring Harbor, NY: Cold Spring Harbor Laboratory.

Thevelein, J. M., Beullens, M., Honshoven, F., Hoebeeck, G., Detremerie, K., den Hollander, J. A. \& Jans, A. W. H. (1987). Regulation of the cAMP level in the yeast Saccharomyces cerevisiae: intracellular $\mathrm{pH}$ and the effect of membrane depolarizing compounds. J Gen Microbiol 133, 2191-2196.

Thomas, D. S. \& Davenport, R. (1985). Zygosaccharomyces bailii-a profile of characteristics and spoilage activities. Food Microbiol 2, 157-169.

Ulazewski, S., Van Herckm, J.-C., Dufour, J.-P., Kulpa, J., Nieuwenhuis, B. \& Goffeau, A. (1987). A single mutation confers vanadate resistance to the plasma membrane $\mathrm{H}^{+}$-ATPase from the yeast Schizosaccharomyces pombe. J Biol Chem 262, 223-228.

Van Uden, N. (1984). Temperature profiles of yeasts. Adv Microb Pbysiol 25, 195-251.

Warth, A. D. (1978). Mechanism of resistance of Saccharomyces bailii to benzoic, sorbic and other weak acids used as food preservatives. $J$ Appl Bacteriol 43, 215-230.

Warth, A. D. (1988). Effects of benzoic acid on growth yields of yeasts differing in their resistance to preservatives. Appl Environ Microbiol 54, 2091-2095.

Watson, K. (1990). Microbial stress proteins. Adv Microb Pbysiol 31, 183-223.

Received 13 July 1993; revised 18 October 1993; accepted 15 November 1993. 